\title{
Perbandingan Cara Pengolahan Kakao Lindak (Bulk Cocoa) pada Perkebunan Besar Negara dan Perkebunan Swasta di Glenmore, Kabupaten Banyuwangi, Jawa Timur
}

\author{
The Compare of Bulk Cocoa Processing on the Government Estate and the Private Estate on \\ Glenmore, Banyuwangi, East Java
}

\author{
Sayi Hatiningsih1)*, Dewa Gde Mayun Permana ${ }^{1)}$, Sony Suwasono ${ }^{2)}$ \\ 1) Program Studi Ilmu dan Teknologi Pangan, Fakultas Teknologi Pertanian, \\ Universitas Udayana, Jl. Raya Kampus Unud, Jimbaran, Kuta Selatan, Badung-Bali \\ 2)Jurusan Teknologi Hasil Pertanian, Fakultas Teknologi Pertanian, Universitas Jember, \\ Jl. Kalimantan 37, Kampus Tegal Boto, Jember 68121 \\ *Email: sayi_hatiningsih@unud.ac.id ${ }^{1)}$
}

\begin{abstract}
The excellent quality of the cocoa beans is closely related to the processing of cocoa beans. This study aimed to compare the processing of bulk cocoa on the government estate and the private estate on Glenmore, Banyuwangi, East Java. The method use observation, interviews, and literature study to record relevant information, then analyzed with descriptive and qualitative analysis. The result showed that the government estate and the private estate on Glenmore, Banyuwangi, East Java did pay attention to the quality of cocoa beans because of the processing methods of cocoa beans of that two cocoa estates had been good, especially with the fermentation of cocoa beans. The processing of cocoa beans on the government estate on Glenmore, Banyuwangi, East Java comprises receiving raw materials, fermentation, washing or rinsing, drying, tempering, sorting, packaging, and storing. The processing of cocoa beans on the private estate on Glenmore, Banyuwangi, East Java comprises receiving raw materials, pressing, fermentation, drying, sorting, packaging, and storing.
\end{abstract}

Keywords: Processing of cocoa beans, Glenmore estate, fermentation

\section{PENDAHULUAN}

\author{
Salah satu komoditas perkebunan di \\ Indonesia yang berperan penting bagi \\ perekonomian nasional maupun regional adalah \\ kakao (Theobroma cacao L.). Produksi kakao di \\ Indonesia terbesar ketiga di dunia setelah Pantai \\ Gading dan Ghana (Dirjen Pengolahan dan \\ Pemasaran Hasil Pertanian, 2013). Kakao telah \\ memberikan sumbangan devisa negara, sumber \\ pendapatan petani, penyedia lapangan kerja \\ petani, mendorong agribisnis dan agroindustri \\ serta pengembangan wilayah (Rosmawaty et al.,
}

2015). Sentra perkebunan kakao ini tersebar di beberapa provinsi di Indonesia meliputi Sulawesi $(63,8 \%)$, Sumatera (16,3\%), Jawa (5,3\%), Maluku dan Papua $(7,1 \%)$, Nusa Tenggara Timur, Nusa Tenggara Barat dan Bali (4,0\%), Kalimantan (3,6\%) (Ditjenbun, 2013).

Dari seluruh luas areal perkebunan kakao di Indonesia pada tahun 2017 sebagian besar dihasilkan oleh perkebunan rakyat $(97,55 \%)$ dan sisanya dihasilkan oleh perkebunan besar negara $(0,89 \%)$ dan perkebunan besar swasta $(1,57 \%)$ 
(Direktorat Jenderal Perkebunan, Deptan, 2016), seperti terlihat pada Tabel 1. Salah satu wilayah penghasil kakao yang cukup besar di Indonesia adalah Jawa Timur dengan jumlah produksi 28.575 ton (Ditjenbun, 2013).

Tabel 1. Luas areal perkebunan kakao di Indonesia tahun 2015-2017

\begin{tabular}{ccccc}
\hline \multirow{2}{*}{ Tahun } & \multicolumn{4}{c}{ Luas Areal (Ha) } \\
\cline { 2 - 5 } & $\begin{array}{c}\text { Perkebunan } \\
\text { Rakyat }\end{array}$ & BUMN & Swasta & Total \\
\hline 2015 & 1.667 .337 & 15.171 & 26.776 & 1.709 .284 \\
2016 & 1.659 .598 & 15.101 & 26.652 & 1.701 .351 \\
2017 & 1.649 .827 & 15.012 & 26.495 & 1.691 .334 \\
\hline
\end{tabular}

Sumber: Diolah dari Statistik Perkebunan Indonesia, Direktorat Jenderal Perkebunan, Deptan, 2016.

Besarnya produksi kakao di Indonesia belum diimbangi dengan mutu kakao yang baik. Sebagian besar kakao yang dihasilkan produsen, terutama yang bersumber dari perkebunan rakyat masih tergolong rendah (Davit et al., 2018). Hal ini dikarenakan biji kakao tidak diolah/difermentasi, dan hanya sedikit petani kakao (kurang dari 20\%) yang mau mengolah biji kakao (Nurhadi et al., 2019), serta biji kakao banyak mengandung kotoran dan jamur (Listiyati Dewi, 2014), sehingga kurang memenuhi standar ekspor kakao yang berlaku di pasar internasional (Ditjenbun, 2012).

Jika dilihat, Tabel 1 menunjukkan bahwa kakao juga diproduksi oleh perkebunan besar negara (Badan Usaha Milik Negara) dan perkebunan swasta, dan salah satu kawasannya ada di Kecamaan Glenmore, Kabupaten Banyuwangi, Jawa Timur. Kakao yang dihasilkan oleh perkebunan besar negara dan perkebunan swasta di wilayah Kecamatan Glenmore, Kabupaten Banyuwangi, Jawa Timur sebagian besar adalah jenis kakao lindak (bulk cocoa). Kakao lindak tersebut dihasilkan melalui teknik budidaya tanaman dan diolah secara wash process yang memperhatikan sistem jaminan mutu GAP (Good Agriculture Practice) dan GMP (Good Manufacturing Practices), sehingga dihasilkan mutu produk kakao yang baik (PTPN12, 2019).

Menurut Duarte et al. (2008), mutu fisik, citarasa dan komposisi kimia hasil perkebunan ditentukan oleh bahan tanam, budidaya, cara panen, pengolahan dan penyimpanannya. Oleh karena itu, pengolahan kakao yang baik dan benar perlu diketahui untuk meningkatkan mutu kakao, terutama cara pengolahan kakao yang sudah dilakukan oleh perkebunan besar negara dan perkebunan besar swasta di wilayah Kecamaan Glenmore, Kabupaten Banyuwangi, Jawa Timur.

\section{METODE}

Penelitian ini menggunakan data primer dan data sekunder. Data primer didapat melalui wawancara dengan narasumber dan responden terpilih serta pengamatan langsung oleh penulis. Sedangkan data sekunder didapat melalui beberapa sumber informasi diantaranya: buku, jurnal dan data statistik sesuai dengan topik 
permasalahan dan pembahasan dalam penelitian. Pengambilan sampel penelitian diperoleh dengan teknik purposive sampling. Responden terpilih adalah penanggungjawab/ kepala pabrik pengolahan kakao dan penanggungjawab setiap tahapan pengolahan kakao di pabrik.

Analisis data diperoleh melalui pendekatan kualitatif eksploratif dengan kerangka penelitian pengolahan kakao lindak (bulk cocoa) pada perkebunan besar negara dan perkebunan swasta. Analisis data meliputi gambaran umum dari objek penelitian berdasarkan data empiris untuk membangun peningkatan mutu kakao para produsen kakao.

\section{HASIL DAN PEMBAHASAN}

Penelitian ini fokus membahas pengolahan kakao lindak (bulk cocoa) pada perkebunan besar negara dan perkebunan swasta, khususnya di wilayah Kecamaan Glenmore, Kabupaten Banyuwangi, Jawa Timur. Menurut Henny dan Mayrowani (2013), pengolahan kakao dibedakan menjadi dua kegiatan besar, pertama adalah penanganan primer mencakup penanganan komoditas sampai menjadi produk setengah jadi/produk siap diolah. Kedua, penanganan sekunder berupa keberlanjutan dari penanganan primer, dari produk setengah jadi hingga menjadi produk kakao siap dikonsumsi. Menurut Wahyudi et.al. (2015), secara umum cara pengolahan kakao meliputi penerimaan bahan baku, fermentasi, perendaman dan pencucian, pengeringan, tempering, sortasi, pengemasan, dan penyimpanan atau penggudangan.

Hasil penelitian menunjukkan bahwa cara pengolahan kakao lindak (bulk cocoa) pada perkebunan besar negara dan perkebunan swasta di Kecamatan Glenmore, Kabupaten Banyuwangi, Jawa Timur hampir sama dengan yang diuraikan oleh Wahyudi et.al. (2015), seperti ditunjukkan pada Tabel 2, Tabel 3, Tabel 4 dan Tabel 5.

Tabel 2, Tabel 3, Tabel 4 dan Tabel 5 menunjukkan bahwa cara pengolahan biji kakao lindak (bulk cocoa) pada kedua perkebunan tersebut hampir sama. Cara pengolahan kakao lindak (bulk cocoa) yang dilakukan oleh perkebunan besar negara di Kecamatan Glenmore, Kabupaten Banyuwangi, Jawa Timur, meliputi: penerimaan bahan baku, fermentasi, pencucian atau pembilasan, pengeringan, tempering, pengemasan, dan penyimpanan atau penggudangan. Sedangkan cara pengolahan biji kakao lindak (bulk cocoa) di perkebunan swasta meliputi: penerimaan bahan baku, pengempresan, fermentasi, pengeringan, sortasi, dan penyimpanan atau penggudangan.

Jika diamati, cara pengolahan biji kakao lindak (bulk cocoa) pada perkebunan besar negara dan perkebunan swasta di Kecamatan Glenmore, Kabupaten Banyuwangi, Jawa Timur sangat memperhatikan mutu kakao dan sudah ada upaya untuk meningkatkan mutu terutama melalui teknologi fermentasi, pengeringan dan sortasi serta standarisasi mutu kakao selama proses pengolahannya. Menurut Manalu (2018), cara pengolahan kakao yang baik terutama dengan adanya fermentasi dapat menghasilkan mutu kakao yang baik, dan selanjutnya berimbas pada nilai ekonomi yang tinggi karena harga biji kakao 
terfermentasi sangat tinggi di pasar terutama pasar internasional.

Salah satu indikator pengolahan kakao yang baik adalah dengan adanya proses fermentasi kakao. Tabel 2 menunjukkan bahwa perkebunan besar negara dan perkebunan swasta sudah melakukan proses fermentasi yang baik pada biji kakao lindaknya. Pada perkebunan besar negara, fermentasi kakao lindak dilakukan selama 4 hari dengan 2 kali pembalikan, sedangkan pada perkebunan swasta fermentasi kakao lindak dilakukan selama 5 hari dengan 2 kali pembalikan. Lamanya fermentasi kakao ini sesuai dengan hasil penelitian Wahyudi et al. (2015) yang mengungkapkan bahwa jenis kakao lindak memiliki waktu fermentasi selama 4-5 hari dengan pengadukan atau pembalikan setelah 48 jam (dua hari).

Fermentasi kakao ini diketahui berpengaruh terhadap jumlah biji kakao per gram (bean account), warna, bentuk/tekstur dalam biji kakao, kadar air, aroma, kecacatan utamanya biji ungu (slaty) serta harga jual produk (Davit et.al., 2013). Hasan et al. (2013) menambahkan bahwa fermentasi kakao dapat membentuk citarasa khas kakao dan mengurangi rasa pahit sehingga dihasilkan kakao bermutu tinggi serta bernilai ekonomi lebih baik, sedangkan kakao yang tidak terfermentasi berwarna ungu pucat, bertekstur pejal, rasanya pahit dan sepat. Menurut Baehaki (2011), adanya inovasi teknologi fermentasi pada pengolahan kakao dapat menghasilkan citarasa kakao yang setara dengan kakao dari negara lain seperti Ghana.
Fermentasi adalah tahapan pengolahan kakao yang mutlak dan vital dilakukan guna menjamin diperolehnya citarasa dan aroma cokelat yang baik (Sepriani dan Arif, 2016; Kresnowati dan Febriani, 2016). Hal ini dikarenakan selama fermentasi terjadi perombakan gula, protein dan senyawa polifenol oleh enzim sehingga terbentuk kenampakan fisik, warna, aroma dan citarasa kakao yang lebih baik (Wahyudi et al., 2008).

Proses fermentasi ini juga diketahui memberikan manfaat yang sama pada komoditas perkebunan lainnya seperti kopi, fermentasi pada kopi diketahui secara signifikan mampu meningkatkan kualitas fisikokimia dan mikrobiologis biji kopi terutama menurunkan kafein pada kandungan biji kopinya (Hatiningsih et al., 2018). Beberapa hal seperti diuraikan diatas diduga kuat yang mendasari perkebunan besar negara dan perkebunan swasta di Kecamatan Glenmore, Kabupaten Banyuwangi, Jawa Timur sudah menerapkan cara pengolahan kakao lindak (bulk cocoa) yang baik terutama dengan teknologi fermentasinya.

\section{KESIMPULAN}

Biji kakao lindak (bulk cocoa) yang dihasilkan oleh perkebunan besar negara dan perkebunan swasta di Kecamatan Glenmore, Kabupaten Banyuwangi, Jawa Timur sudah diolah dengan cara yang baik, terutama dengan adanya proses fermentasi kakao sehingga mutu kakaonya lebih tinggi. Proses pengolahan biji kakao lindak (bulk cocoa) di perkebunan besar negara di Kecamatan Glenmore, Kabupaten Banyuwangi, Jawa Timur meliputi penerimaan bahan baku, 
fermentasi, pencucian atau pembilasan, kakao yang baik terutama dengan adanya proses pengeringan, tempering, sortasi, pengemasan, dan fermentasi biji kakao telah dilakukan oleh penyimpanan atau penggudangan. Proses perkebunan besar negara dan perkebunan swasta pengolahan biji kakao lindak (bulk cocoa) di di Kecamatan Glenmore, Kabupaten Banyuwangi, perkebunan swasta di Kecamatan Glenmore, Jawa Timur sehingga biji kakao yang dihasilkan Kabupaten Banyuwangi, Jawa Timur meliputi: sesuai dengan standar mutu SNI biji kakao (SNI penerimaan bahan baku, pengempresan, 2323:2008/Amd I:2010) dan syarat mutu yang fermentasi, pengeringan, sortasi, dan dibutuhkan oleh pasar internasional. penyimpanan atau penggudangan. Pengolahan biji 
Tabel 2. Perbandingan cara pengolahan kakao lindak (bulk cocoa) pada perkebunan besar negara dan perkebunan swasta di Kecamatan Glenmore, Kabupaten Banyuwangi, Jawa Timur

\begin{tabular}{|c|c|c|}
\hline $\begin{array}{c}\text { Tahapan } \\
\text { Pengolahan } \\
\text { Kakao }\end{array}$ & Perkebunan Besar Negara & Perkebunan Swasta \\
\hline $\begin{array}{l}\text { Penerimaan } \\
\text { Bahan Baku }\end{array}$ & $\begin{array}{l}\text { - Biji kakao basah hasil panen ditimbang (selisih antara } \\
\text { kebun dan pabrik maksimal 2,5\%) } \\
\text { - Dilakukan uji petik biji kakao basah dengan cara } \\
\text { mengambil sampel dari masing-masing karung sesuai } \\
\text { jenis mutunya sebanyak } 5 \mathrm{~kg} \text { untuk dianalisa mutunya } \\
\text { meliputi plasenta, biji inferior, kulit kolven, benda-benda } \\
\text { asing dan biji normal }\end{array}$ & $\begin{array}{l}\text { - Biji kakao basah hasil panen ditimbang (selisih antara } \\
\text { kebun dan pabrik maksimal 2,5\%) } \\
\text { - Dilakukan uji petik biji kakao basah dengan cara } \\
\text { mengambil sampel dari masing-masing karung sesuai jenis } \\
\text { mutunya sebanyak } 5 \mathrm{~kg} \text { untuk dianalisa mutunya meliputi } \\
\text { plasenta, tidak normal (abnormal), biji berkecambah } \\
\text { (sprout), biji busuk (rotten), biji pecah (broken bean), } \\
\text { kontaminasi (contamination), biji terlalu matang (over } \\
\text { ripe), biji terlalu muda (under ripe), dan biji normal } \\
\text { - Batas maksimal biji inferior, kotoran dan benda asing pada } \\
\text { uji petik sebesar 1,5\% }\end{array}$ \\
\hline Pengempresan & - Tidak dilakukan & $\begin{array}{l}\text { - Menggunakan mesin press atau elektromotor hidraulik } \\
\text { press berkapasitas } 750 \mathrm{~kg} \text { selama 3-5 jam }\end{array}$ \\
\hline Fermentasi & $\begin{array}{l}\text { - Selama } 4 \text { hari } \\
\text { - Pembalikan sebanyak } 2 \text { kali pada hari ke- } 2 \text { dan ke-3 } \\
\text { - Kotak fermentasi terbuat dari kayu, ukuran } 174 \times 174 \times 60 \text {, } \\
\text { tebal } 2-3 \mathrm{~cm} \text {, diameter lubang aerasi } 1 \mathrm{~cm} \text {, jarak antar- } \\
\text { lubang sama berkisar } 4-5 \mathrm{~cm} \text {, berkapasitas } 1,5 \text { ton dan } \\
\text { dipasang label pada kotak fermentasinya } \\
\text { - Tumpukan biji kakao basah ditutup karung goni } \\
\text { - Dilakukan pengecekan suhu pada tumpukan biji kakao } \\
\text { basah selama fermentasi berlangsung } \\
\text { - Sebelum dan pasca-fermentasi, kotak fermentasi harus } \\
\text { dalam keadaan bersih termasuk lubang kotak } \\
\text { fermentasinya }\end{array}$ & $\begin{array}{l}\text { - Selama } 5 \text { hari } \\
\text { - Pembalikan sebanyak } 2 \text { kali pada hari ke-2 dan ke-4 } \\
\text { - Kotak fermentasi terbuat dari kayu, ukuran } 350 \times 160 \text { x65 } \\
\text { cm (untuk hari ke-1 dan ke-2), ukuran } 300 \text { x } 160 \text { x } 55 \mathrm{~cm} \\
\text { (untuk hari ke-3, ke-4, dan ke-5), tebal } 3-4 \mathrm{~cm} \text {, diameter } \\
\text { lubang aerasi } 1 \mathrm{~cm} \text {, jarak antar-lubang acak berkisar 3-10 } \\
\text { cm, berkapasitas } 2,5 \text { ton dan dipasang label pada kotak } \\
\text { fermentasinya } \\
\text { - Tumpukan biji kakao basah ditutup karung goni } \\
\text { - Dilakukan pengecekan suhu pada tumpukan biji kakao } \\
\text { basah selama fermentasi berlangsung } \\
\text { - Sebelum dan pasca-fermentasi, kotak fermentasi harus } \\
\text { dalam keadaan bersih termasuk lubang kotak fermentasinya }\end{array}$ \\
\hline
\end{tabular}




\begin{tabular}{ll}
\hline $\begin{array}{l}\text { Pencucian atau } \\
\text { pembilasan }\end{array}$ & $\begin{array}{c}\text { Biji kakao terfermentasi direndam air selama } 3 \text { jam, } \\
\text { dikucek perlahan lalu dibilas dengan air mengalir }\end{array}$ \\
& - Dilakukan jika ada permintaan khusus bagi konsumen
\end{tabular}

Tabel 3. Perbandingan cara pengolahan kakao lindak (bulk cocoa) pada perkebunan besar negara dan perkebunan swasta di Kecamatan Glenmore, Kabupaten Banyuwangi, Jawa Timur (Lanjutan)

\begin{tabular}{|c|c|c|}
\hline $\begin{array}{c}\text { Tahapan } \\
\text { Pengolahan } \\
\text { Kakao }\end{array}$ & Perkebunan Besar Negara & Perkebunan Swasta \\
\hline Pengeringan & $\begin{array}{l}\text { - Jika cuaca cerah dilakukan pengeringan kombinasi, } \\
\text { pengeringan tahap I dengan penjemuran selama } 1-3 \text { hari } \\
\text { dan dibalik } 2 \text { jam sekali hingga kadar air } 17-20 \% \text {, } \\
\text { pengeringan tahap II menggunakan mesin vis dryer (suhu } \\
70^{\circ} \mathrm{C} \text { selama } 20 \text { jam) atau menggunakan cocoa dryer (suhu } \\
70^{\circ} \mathrm{C} \text { selama } 20 \text { jam) dan dibalik } 2 \text { jam sekali hingga kadar } \\
\text { airnya } 7 \% \\
\text { - Jika cuaca mendung/hujan hanya dilakukan pengeringan } \\
\text { mekanis menggunakan mesin vis dryer (suhu } 55^{\circ} \mathrm{C} \text { selama } \\
55 \text { jam) atau menggunakan cocoa dryer (suhu } 55^{\circ} \mathrm{C} \text { selama } \\
55 \text { jam) dan dibalik } 2 \text { jam sekali hingga kadar airnya } 7 \% \\
\text { - Sumber panas berupa udara panas dihasilkan oleh tungku } \\
\text { berbahan bakar kayu bakar }\end{array}$ & $\begin{array}{l}\text { - Pengeringan tahap I dengan menggunakan mesin circular } \\
\text { drier (kapasitas } 10 \text { ton, suhu } 60^{\circ} \mathrm{C} \text { selama } 24 \text { jam dengan } \\
\text { kecepatan rotasi putaran alatnya sebesar } 3 \mathrm{rpm} \text {, dilengkapi } \\
\text { unit pengaduk) hingga kadar airnya } 17-20 \% \text {, pengeringan } \\
\text { tahap II dengan menggunakan rotary drier (kapasitas } 10 \\
\text { ton, suhu } 60-70^{\circ} \mathrm{C} \text { selama } 30 \text { jam dengan kecepatan rotasi } \\
\text { putaran alatnya sebesar } 1 / 3 \mathrm{rpm} \text { ) atau mason drier } \\
\text { (kapasitas } 18 \text { ton, suhu } 70-80^{\circ} \mathrm{C} \text { selama } 20-36 \text { jam dengan } \\
\text { kecepatan rotasi putaran alatnya sebesar } 1 / 1,72 ; 1 / 1,6 \text {; } \\
1 / 1,83 \mathrm{rpm} \text { ) hingga kadar airnya } 7 \% \\
\text { - Pengeringan kombinasi dilakukan untuk biji kakao basah } \\
\text { mutu inferior } \\
\text { - Sumber panas berupa udara panas dihasilkan oleh air } \\
\text { heater/tungku berbahan bakar batu bara/kayu bakar }\end{array}$ \\
\hline Tempering & $\begin{array}{l}\text { - Biji kakao kering dikemas dalam karung lalu disimpan } \\
\text { dalam gudang tempering selama 2-3 hari } \\
\text { - Penimbunan karung berisi biji kakao kering perjenis mutu, } \\
\text { ditutup terpal dan dipasang label dengan batas tumpukan } 5 \\
\text { karung } \\
\text { - Dilakukan pengaturan ventilasi ruangan agar suhu berkisar } \\
27^{\circ} \mathrm{C} \text { dan kelembaban } 75-80 \% \\
\text { - Gudang tempering harus bersih dan bebas hama }\end{array}$ & $\begin{array}{l}\text { - Tidak dilakukan } \\
\text { - Prinsip kerjanya hampir sama dengan tempering yakni } \\
\text { biji kakao kering disimpan dalam silo (kapasitas } 3 \text { ton) } \\
\text { selama 2-3 hari }\end{array}$ \\
\hline
\end{tabular}




\begin{tabular}{|c|c|c|}
\hline Sortasi & $\begin{array}{l}\text { - jika produksi kakao melimpah, biji kakao kering disimpan } \\
\text { dalam silo sebelum disortasi } \\
\text { - Sortasi diawali dengan proses pengayakan dengan } \\
\text { menggunakan tampah ayak berlubang untuk diperoleh } \\
\text { ukuran biji kakao kering yang seragam } \\
\text { - Sortasi biji kakao kering dengan cara manual menggunakan } \\
\text { meja sortasi yang sudah dilengkapi kotak-kotak kecil pada } \\
\text { meja sortasi untuk memisahkan biji kakao kering sesuai } \\
\text { kelas mutunya }\end{array}$ & $\begin{array}{l}\text { - Sortasi dilakukan cara mekanis menggunakan alat } \\
\text { penyortir (kapasitas } 1 \text { ton, kecepatan rotasinya } 8 \mathrm{rpm} \text {, laju } \\
\text { aliran } 1 \text { ton/jam), yang dilengkapi lapisan-lapisan atau } \\
\text { plat berbentuk silinder, semakin keluar lapisan plat maka } \\
\text { lubang-lubang pada plat semakin kecil untuk } \\
\text { memisahkan biji kering sesuai kelas mutunya, serta } \\
\text { dilengkapi kipas yang mampu menghembuskan aliran } \\
\text { udara sehingga membantu memisahkan residu kotoran- } \\
\text { kotoran ringan dan benda asing yang ada pada biji kakao } \\
\text { kering }\end{array}$ \\
\hline
\end{tabular}

Tabel 4. Perbandingan cara pengolahan kakao lindak (bulk cocoa) pada perkebunan besar negara dan perkebunan swasta di Kecamatan Glenmore, Kabupaten Banyuwangi, Jawa Timur (Lanjutan II)

\begin{tabular}{|c|c|c|}
\hline $\begin{array}{c}\text { Tahapan } \\
\text { Pengolahan } \\
\text { Kakao }\end{array}$ & Perkebunan Besar Negara & Perkebunan Swasta \\
\hline $\begin{array}{l}\text { Sortasi } \\
\text { (lanjutan) }\end{array}$ & $\begin{array}{l}\text { - Biji kakao kering diuji jumlah biji/100 gram } \\
\text { (bean count) dan jenis mutunya untuk } \\
\text { selanjutnya dibandingkan dengan hasil uji } \\
\text { petik pada biji kakao basah saat proses } \\
\text { penerimaan bahan baku } \\
\text { - Cara menguji mutu biji kakao kering adalah } \\
\text { mengambil sampel sebanyak } 200 \text { gram per } \\
\text { karung yang telah diberikan penyortir, } \\
\text { dicampur jadi satu hingga sebanyak } 5 \mathrm{~kg} \\
\text { lalu dimbil secara acak } 100 \text { gram untuk } \\
\text { setiap uji dan dilakukan sebayak } 3 \text { kali } \\
\text { ulangan kerakg dicek mutunya } \\
\text { - Biji kakao kering } \\
\text { berdasarkan SNI 2323:2008/Amd I:2010 } \\
\text { dan kelas mutunya meliputi mutu ekspor, }\end{array}$ & $\begin{array}{l}\text { - Biji kakao kering diuji jumlah biji/100 gram (bean count) dan jenis mutunya } \\
\text { untuk selanjutnya dibandingkan dengan hasil uji petik pada biji kakao basah } \\
\text { saat proses penerimaan bahan baku } \\
\text { - Cara menguji mutu biji kakao kering adalah mengambil sampel sebanyak } \\
200 \text { gram per karung yang telah diberikan penyortir, dicampur jadi satu } \\
\text { hingga sebanyak } 5 \mathrm{~kg} \text { lalu dimbil secara acak } 100 \text { gram untuk setiap uji dan } \\
\text { dilakukan sebayak } 3 \text { kali ulangan } \\
\text { - Biji kakao kering dicek mutunya berdasarkan SNI 2323:2008/Amd I:2010 } \\
\text { dan kelas mutunya meliputi mutu ekspor/grade } 1 \text { (warna cokelat, utuh, biji } \\
\text { terfermentasi, dikeringkan mekanis), grade } 2 \text { (warna cokelat, utuh, biji tidak } \\
\text { terfermentasi, dikeringkan cara kombinasi), kepeng (warna cokelat, bentuk } \\
\text { gepeng dan tidak/sedikit berisi nib), EX.CPB (warna cokelat, bentuk } \\
\text { brongkolan) dan residu (warna cokelat, campuran biji pecah, serbuk dan } \\
\text { kulit biji) } \\
\text { - Spesifikasi mutu biji kakao kering grade } 1 / \text { ekspor lebih detail meliputi: }\end{array}$ \\
\hline
\end{tabular}


mutu lokal (BP, bongkahan dan kepek), persyaratan umumnya meliputi ada tidaknya serangga hidup: tidak ada, kadar air (b/b): maks. 7,5, biji berbau asap/bau asing: tidak ada, kadar benda asing (b/b): tidak ada, dan kadar biji pecah $(\mathrm{b} / \mathrm{b})$ : maks.2. Persyaratan khusus meliputi ukuran biji kakao menurut SNI 2323:2008 biji kakao, kadar biji berjamur (biji/biji), kadar biji slaty (biji/biji), kadar kotoran/waste (b/b), kadar biji berkecambah (biji/biji), secara periodik juga diuji $\mathrm{pH}$ dan kadar lemak bijinya jumlah biji/100 gram/ bean count $(<100)$, bean uniformity above $1 / 3 A v$, Bean $(<12 \%)$, below $1 / 3 \mathrm{Av}$, Bean $(<12 \%)$, tingkat keasaman/pH biji $(>5,2)$, kadar air biji/whole bean VM $(<7 \%)$, kadar air biji tanpa kulit/nib $(<6,1 \%)$, kulit biji/shell dalam 100g $(<12)$, kecambah/germ $(<0,9 \%)$, kadar lemak/fat on dry nib (>55\%), value (>44,5), biji terfermentasi/well fermented dalam 100 biji (>90), biji tidak terfermentasi/purple/slaty dalam 100 biji $(<10)$, biji dempet/double bean $(<0,5 \%)$, kadar kotoran/waste dalam $1 \mathrm{~kg}(<1,5 \%)$, serangga/presence of live insect (tidak ada), kadar biji pecah/broken beans (maks.2), kadar benda asing/foreign metter (tidak ada), biji berkapang/mouldy beans (maks. 2), biji kurang terfermentasi/unfermented beans (maks.3), biji berserangga/insect damaged (maks.1), biji berkecambah/germinated beans (maks. 2) dan dapat digolongkan mutu I (SNI 2323:2008/Amd I:2010)

- Biji kakao kering dikemas dalam karung goni dan karung plastik sesuai kelas mutunya

- Biji kakao kering mutu ekspor seberat 62,5 kg, dikemas dengan karung goni (ukuran 74 x $110 \mathrm{~cm}$, berat $1 \mathrm{~kg}$, kapasitas $80 \mathrm{~kg}$ )

Tabel 5. Perbandingan cara pengolahan kakao lindak (bulk cocoa) pada perkebunan besar negara dan perkebunan swasta di Kecamatan Glenmore, Kabupaten Banyuwangi, Jawa Timur (Lanjutan III)

\begin{tabular}{|c|c|c|}
\hline $\begin{array}{c}\text { Tahapan } \\
\text { Pengolahan } \\
\text { Kakao }\end{array}$ & Perkebunan Besar Negara & Perkebunan Swasta \\
\hline $\begin{array}{l}\text { Pengemasan } \\
\text { (lanjutan) }\end{array}$ & $\begin{array}{l}\text { - Biji kakao kering mutu ekspor seberat } 62,5 \mathrm{~kg} \text {, } \\
\text { dikemas dengan karung goni (ukuran } 74 \times 110 \\
\mathrm{~cm} \text {, berat } 1 \mathrm{~kg} \text {, kapasitas } 80 \mathrm{~kg} \text { ) } \\
\text { - Biji kakao kering mutu lokal seberat } 50 \mathrm{~kg} \text {, } \\
\text { dikemas dengan karung plastik (ukuran } 74 \times 110 \\
\mathrm{~cm} \text {, berat } 0,2 \mathrm{~kg} \text {, kapasitas } 100 \mathrm{~kg} \text { ) } \\
\text { - Untuk memudahkan penyimpanan dan } \\
\text { pengiriman, karung goni diberi label yang berisi }\end{array}$ & $\begin{array}{l}\text { - Untuk memudahkan penyimpanan dan pengiriman, karung goni } \\
\text { diberi label yang berisi logo perusahaan, kelas mutu, no kavling, no }\end{array}$ \\
\hline
\end{tabular}




\begin{tabular}{|c|c|c|}
\hline & $\begin{array}{l}\text { logo perusahaan, kelas mutu, no kavling, no } \\
\text { karung, tahun, dan berat netto dengan } \\
\text { menggunakan cat berpelarut air yang tidak luntur } \\
\text { dan non-toksik }\end{array}$ & $\begin{array}{l}\text { karung, tahun, dan berat netto dengan menggunakan cat berpelarut } \\
\text { air yang tidak luntur dan non-toksik }\end{array}$ \\
\hline $\begin{array}{l}\text { Penyimpanan } \\
\text { atau } \\
\text { Penggudangan }\end{array}$ & $\begin{array}{l}\text { - Gudang penyimpanan harus bersih dan bebas } \\
\text { hama serta dilakukan pengaturan ventilasi } \\
\text { ruangan agar suhu berkisar } 27^{\circ} \mathrm{C} \text { dan } \\
\text { kelembaban <75\% } \\
\text { - Pemasukan dan pengeluaran karung berisi biji } \\
\text { kakao kering menggunakan sistem FIFO (first in } \\
\text { first out) } \\
\text { - Penimbunan/penumpukan karung berisi biji } \\
\text { kakao kering disesuaikan tempatnya } \\
\text { perjenis/kelas mutu } \\
\text { - Batas tumpukan karung goni berisi biji kakao } \\
\text { kering mutu ekspor adalah } 12 \text { tumpukan, } \\
\text { sedangkan batas tumpukan karung plastik berisi } \\
\text { biji kakao kering mutu lokal adalah } 6 \text { tumpukan } \\
\text { - Tumpukan karung berisi biji kakao kering } \\
\text { diletakkan pada papan kayu kering dengan } \\
\text { rangka bawah dari kayu setinggi sekitar } 60 \mathrm{~cm} \\
\text { dari lantai dengan jarak dari dinding gudang } \\
\text { sekitar } 15-20 \mathrm{~cm} \\
\text { - Dilakukan fumigasi secara periodik }\end{array}$ & $\begin{array}{l}\text { - Gudang penyimpanan harus bersih dan bebas hama serta dilakukan } \\
\text { pengaturan ventilasi ruangan agar suhu berkisar } 27^{\circ} \mathrm{C} \text { dan } \\
\text { kelembaban <75\% } \\
\text { - Pemasukan dan pengeluaran karung berisi biji kakao kering } \\
\text { menggunakan sistem FIFO (first in first out) } \\
\text { - Penimbunan/penumpukan karung berisi biji kakao kering } \\
\text { disesuaikan tempatnya perjenis/kelas mutu } \\
\text { - Batas tumpukan karung goni berisi biji kakao kering mutu ekspor } \\
\text { adalah } 12 \text { tumpukan, sedangkan batas tumpukan karung plastik } \\
\text { berisi biji kakao kering mutu lokal adalah } 6 \text { tumpukan } \\
\text { - Tumpukan karung berisi biji kakao kering diletakkan pada papan } \\
\text { kayu kering dengan rangka bawah dari besi setinggi sekitar } 60 \mathrm{~cm} \\
\text { dari lantai dengan jarak dari dinding gudang sekitar } 15-20 \text { cm } \\
\text { - Proses fumigasi pada gudang penyimpanan biji kakao kering } \\
\text { dilakukan secara periodik untuk mencegah atau menghilangkan } \\
\text { hama dan serangga. Proses ini dilakukan dengan cara pemberian } \\
\text { fumigan atau antijamur yaitu kapsul Detia Photoxin sebanyak 2-5 } \\
\text { kapsul/ton. Selanjutnya kakao ditutup atau dibungkus dengan } \\
\text { lembaran plastik sheet di atasnya selama 1-3 hari }\end{array}$ \\
\hline
\end{tabular}




\section{DAFTAR PUSTAKA}

Baehaki. 2011. Strategi Fundamental Pengendalian Hama Wereng Batang Coklat dalam Pengamanan Produksi Padi Nasional. Jurnal Pengembangan Inovasi Pertanian. Vol. 4 (1): 63-75.

Ditjenbun. 2012. Pedoman Umum Gerakan Nasional Peningkatan Produksi dan Mutu Kakao. Kementan, Jakarta.

Dirjen Pengolahan dan Pemasaran Hasil Pertanian. 2013. Pedoman Teknis Pengembangan Mutu Kakao. Jakarta: Dirjen Pengolahan dan Pemasaran Hasil Pertanian.

Ditjenbun. 2013. Pedoman Teknis Penanganan Pasca Panen Tanaman Kakao. Kementan, Jakarta.

Ditjenbun. 2016. Statistik Perkebunan Indonesia Komoditas Kakao 2015-2017. Kementan, Jakarta.

Davit, J.M., Puspa, R.Y., dan Ayu, D.S.Y. 2013. Pengaruh Cara Pengolahan Kakao Fermentasi dan Non-Fermentasi terhadap Kualitas, Harga Jual Prodk pada Unit Usaha Produktif (UUP) Tunjung Sari, Kabupaten Tabanan. E-jurnal Agribisnis dan Agrowisata. Vol. 2 (4): 191-203.

Duarte, G.; A. Pereira \& A. Farah. 2008. Chemical composition of Brazilian Green Coffee Seeds Processed by Dry and Wet Post Harvesting Methods. Proceedings 22nd International Conference on Coffee Science (ASIC) 2008. Hal. 593-596. Campinas, Brazil.

Hasan, Nusyirwan dan Roswita, Rifda. 2013. Peningkatan Produktivitas dan Mutu Kakao melalui Diseminasi Multi-Channel (DMC) di Nagari Parit Malintang, Kabupaten Padang Pariaman. Jurnal Teknologi Pertanian. Vol. 8 (2).

Hatiningsih, S., Antara, N.S., dan Gunam, I.B.W. 2018. Microbiological and Physicochemical
Changes of Green Coffee (Coffea arabica) Fermentation in Kintamani, Bangli, Bali. Media Ilmiah Teknologi Pangan. Vol. 5 (2): 123-138.

Henny, Mayrowani. 2013. Kebijakan Penyediaan Teknologi Pascapanen Kopi dan Masalah Pengembangannya. Jurnal Forum Penelitian Agro Ekonomi. Vol. 31 (1): 31 - 49.

Kresnowati, M.T.A.P. and Febriami, H., (2016), Mapping the Effects of Starter Culture Addition on Cocoa Bean Fermentation. ASEAN Engineering Journal Part B. Vol. 5 (1): 25-37.

Listiyati D., Agus W., dan Hasibuan., M.A. 2014. Penguatan Kelembagaan untuk Peningkatan Posisi Tawar Petani dalam Sistem Pemasaran Kakao. Jurnal Tanaman Industri dan Penyegar. Balai Penelitian Tanaman Industri dan Penyegar, Sukabumi.

Manalu, R. 2018. Pengolahan Biji Kakao Produksi Perkebunan Rakyat untuk Meningkatkan Pendapatan Petani. Jurnal Ekonomi dan Kebijakan Publik. Vol. 9 (2): 99-111.

Nurhadi, E., Hidayat, S.I., Indah, P.N., Widayanti, S., dan Harya, G.I. 2019. Keberlanjutan Komoditas Kakao sebagai Produk Unggulan Agroindustri dalam Meningkatkan Kesejahteraan Petani. Agriekonomika. Vol. (1): 51-61.

PTPN 12. 2019. Mengenal Kakao Jenis Bulk. https://ptpn12.com/2019/07/10/mengenalkakao-jenis-bulk/. [diakses 20 Mei 2020].

Puslitkoka. 2006. Standar Prosedur Operasional (SPO) Pengolahan Kakao. Jember: Pusat Penelitain Kopi dan Kakao.

Rosmawaty., Baka, La. R., Bahari., Taridala, S. A., Saediman, H. 2015. Development Potential of Cocoa Agroindustry in Southeast Sulawesi, Indonesia. Journal of Agriculture and Veterinary Science. Vol. 8 (9): 39-44. 
Septiani, Erina, dan Abdullah, B.A. 2016. Pengaruh Suhu Pemastaan terhadap Rendemen dan Kadar Lemak Bubuk Kakao Hasil Pengempaan dan Biji Kakao Fermentasi dan Non Fermentasi. Jurnal Penelitian Pasca Panen Pertanian. Vol. 13 (1).

Wahyudi, R. (2008) Panduan Lengkap Kakao Manajemen dari Hulu hingga Hilir. Jakarta: Penebar Swadaya Jakarta.

Wahyudi, T., Pujiyanto, dan Misnawi. 2015. Kakao (Sejarah, Botani, Proses Produksi, Pengolahan, dan Perdagangan). Yogyakarta: Gadjah Mada University Press. 